\title{
Estrogen Receptors and Biologic Response in Rat Parathyroid Tissue and C Cells
}

Tally Naveh-Many, Gideon Almogi, Nelly Livni, * and Justin Silver

Minerva Center in Calcium and Bone Metabolism, Nephrology Services; and * Department of Pathology,

Hadassah University Hospital, Jerusalem il-91120, Israel

\begin{abstract}
The expression of the PTH and calcitonin genes is dramatically decreased by $1,25(\mathrm{OH})_{2} \mathrm{D}_{3}$ in vivo, and the PTH gene expression is increased by hypocalcemia. We have now studied the effect of estrogens on the expression of these genes in vivo. $17 \beta$-Estradiol, given to ovariectomized rats, led to a fourfold increase in PTH mRNA and calcitonin mRNA levels. These effects occurred $24 \mathrm{~h}$ after single injections of 37-145 nmol estradiol, or after constant infusions of $12 \mathrm{pmol} / \mathrm{d}$ for 1 or $2 \mathrm{wk}$, where there was no effect on serum calcium levels. The estrogen receptor mRNA was demonstrated in the thyroparathyroid tissue by polymerase chain reaction. The estrogen binding was localized to the parathyroid and $\mathbf{C}$ cells by immunohistochemistry. Uterus weight was increased by repeated larger doses $(73 \mathrm{nmol} / \mathrm{d} \times 7)$ of estradiol, but not by the small doses (12 pmol/d for 1 or 2 wk) which were effective on the PTH and calcitonin genes, suggesting a sensitive endocrine effect. These results confirm that the parathyroid and $C$ cells are target organs for estrogen, leading to an increased expression of PTH and calcitonin, which by their combined anabolic effect on bone would help prevent osteoporosis. (J. Clin. Invest. 1992. 90:2434-2438.) Key words: parathyroid hormone • calcitonin • osteoporosis • calcium • estrogens
\end{abstract}

\section{Introduction}

The expression of the PTH and calcitonin genes are both markedly decreased by $1,25(\mathrm{OH})_{2} \mathrm{D}_{3}$ both in vivo in rats (1-3) and in vitro (4-6). The PTH gene's expression is also regulated by calcium, where the major effect is that of a low calcium increasing PTHmRNA levels in vivo $(2,7)$. In contrast, calcitonin gene expression is not regulated by calcium in vivo (7). At the level of secretion, calcium is the major regulator for both PTH, and calcitonin, with a low calcium being the secretagogue for PTH, and a high calcium for calcitonin.

The major metabolic bone disease is osteoporosis, and in postmenopausal osteoporosis estrogen replacement therapy is the most effective treatment. However, the mechanism of estrogen effect on bone remains to be fully explained. Part of the effect is in all probability due to a direct effect of estrogens on

The results of this study were presented in part at the American Society for Bone and Mineral Research, San Diego, CA, 24-28 August 1991, and were published in abstract form (1991. J. Bone Miner. Res. 6:S282).

Address correspondence to Dr. Justin Silver, Nephrology Services, Hadassah University Hospital, P. O. Box 12000, Jerusalem, Israel il91120.

Received for publication 25 February 1992 and in revised form 16 June 1992.

J. Clin. Invest.

(C) The American Society for Clinical Investigation, Inc. 0021-9738/92/12/2434/05 \$2.00

Volume 90, December 1992, 2434-2438 bone. Osteoblasts have been shown to have estrogen receptors $(8,9)$, and the addition of estrogens to bone cell lines has been shown to have functional effects $(10-12)$ including the synthesis of growth factors such as transforming growth factor $\beta$ and insulin-like growth factors I and II (13-15). These findings demonstrate that estrogens act directly on bone. Estrogens might also have an indirect effect on bone by regulating the production of the calcium regulating hormones. In vitro studies have shown that estrogens increase the secretion of PTH from both bovine and human parathyroid tissue, and increase the secretion of calcitonin from a medullary carcinoma cell line (16-19). We have now studied the regulation of PTH and calcitonin gene expression in vivo in the rat, and the presence of the estrogen receptor $\mathrm{mRNA}$ and protein in the rat parathyroid and $C$ cells.

\section{Methods}

Animals. Female rats of the Hebrew University strain weighing 150 $170 \mathrm{~g}$ were anesthetized by pentobarbitol, and bilateral ovariectomies performed. Other rats had sham operations performed. The rats were maintained on a normal diet for $2 \mathrm{wk}$ when they were then administered various treatments. The rats, four in each group, were given no treatment (sham and ovariectomized), or 17 $\beta$-estradiol (37-145 $\mathrm{nmol} / \mathrm{d})$. The $\beta$-estradiol $\left(\beta \mathrm{E}_{2}\right)$ was given either as a single injection intraperitoneally (i.p.), as daily injections i.p. for $7 \mathrm{~d}$, or as minipumps for 1 or $2 \mathrm{wk}$ in a much lower dose of $12 \mathrm{pmol} / \mathrm{d}$. The rats were then anesthetized blood samples taken, and the thyroparathyroid tissue excised under pentobarbital anesthesia, snap frozen in liquid nitrogen, and stored at $-70^{\circ} \mathrm{C}$ until extraction. The rat uteruses were removed and weighed.

RNA extraction and hybridization. RNA was extracted from rat thyroparathyroid tissue by RNAzol (Biotex, Houston, TX). Between 5 and $10 \mu \mathrm{g}$ of total RNA were used, consisting of RNA from all the tissues in a single rat's thyroparathyroid tissue, including parathyroids, C cells, and thyroid follicles. RNA was analyzed by dot blots and Northern blots by hybridization with radiolabeled cDNA probes $(2-5$ $\times 10^{8} \mathrm{cpm} / \mu \mathrm{g}$ ), autoradiographed; and the films scanned with a densitometer. For each experiment analyzed by dot blot the same amount of total thyroparathyroid tissue RNA was used. The filters were extensively washed and then rehybridized with further probes. The rat PTH cDNA is an 833-bp fragment, the calcitonin probe is an $\sim 900 \mathrm{bp}$ fragment. The filters were also hybridized with control genes, using somatostatin cDNA, actin cDNA, and the $1,25(\mathrm{OH})_{2} \mathrm{D}_{3}$ receptor probes as in our published methodologies $(1,3,20)$. In both the dot blots and the Northern blots the sequence of hybridization with different probes was random. For gel blot analysis the same amounts of RNA were run for all samples as quantitated by ethidium bromide staining and by spectrophotometry $\left(\mathrm{OD}_{260} / \mathrm{OD}_{280}=2\right)$. Results for dot blots are shown as the mean $\pm \mathrm{SE}$ for four rats.

Polymerase chain reaction (PCR). ${ }^{1}$ PCR for the estrogen receptor gene in rat thyroparathyroid tissue RNA extracts was performed (21, 22). RNA was reverse transcribed into first strand cDNA using a kit (Amersham Corp., Arlington Heights, IL). PCR amplification of the cDNA was performed in a $50 \mu \mathrm{l}$ reaction mix containing $2 \mathrm{mM}$ dNTP,

1. Abbreviation used in this paper: PCR, polymerase chain reaction. 
$5 \mu \mathrm{l} 10 \times$ TaqI buffer 100-200 ng each of the upstream and downstream oligonucleotides specific to the rat estrogen receptor 3' end of the gene (23) (synthesized in a DNA synthesizer) and $2.5 \mathrm{u}$ of Taq DNA polymerase (Boehringer Mannheim Corp., Indianapolis, IN). The oligonu-
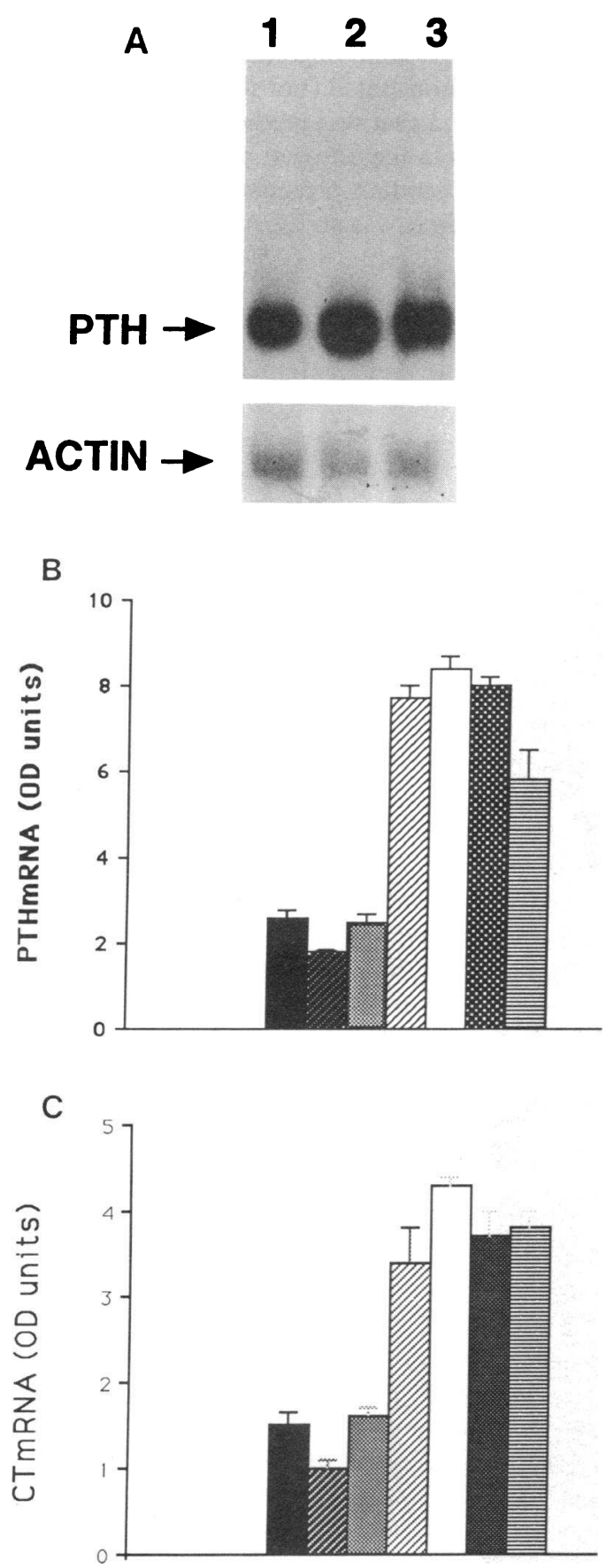

Figure 1. Effect of estrogens on PTH mRNA and calcitonin mRNA in rat thyroparathyroid tissue. $(A)$ Agarose gel electrophoresis of RNA $(6 \mu \mathrm{g})$ from a single rat hybridized for PTH mRNA and actin mRNA. Lanes: 1 , ovariectomized; 2, $17 \beta$-estradiol; 3, sham. (B) PTH mRNA levels derived from dot blots from sham operated, ovariectomized (OVX), and ovariectomized rats given $17 \beta$-estradiol (E). E was given in single doses $(\times 1)$ of 37,73 , and $145 \mathrm{nmol}$, or $12 \mathrm{pmol} / \mathrm{d}$ as a continuous infusion by minipump for 7 or $14 \mathrm{~d}$. $(C)$ Calcitonin mRNA levels in sham, ovariectomized, and E-treated rats. Results for dot blots are shown as the mean \pm s.e.m. for four rats. $₫$, Sham; $n$, OVX; a, E, $37 \mathrm{nmol} \times 1$; 圆, E, $73 \mathrm{nmol} \times 1$;, E, $145 \mathrm{nmol} \times 1$; $\square$ E minipump, $12 \mathrm{pmol} / \mathrm{d} \times 7$; $\mathrm{E}$ minipump, $12 \mathrm{pmol} / \mathrm{d} \times 14$. cleotide primers used were 5'-TGACTCTGCAGCAACAGCAT-3', and 5'-GAGTTCTCAGATGGTGTTGG-3'. The oligonucleotide primers were $311 \mathrm{bp}$ apart. The reaction mixture was covered with mineral oil and subjected to 30 cycles of PCR amplification consisting of $1.5 \mathrm{~min}$ at $56^{\circ} \mathrm{C}, 2 \mathrm{~min}$ at $95^{\circ} \mathrm{C}$, and $1.5 \mathrm{~min}$ at $72^{\circ} \mathrm{C} .10 \mu \mathrm{l}$ of each PCR reaction were analyzed by electrophoresis in $2 \%$ agarose gels, transferred onto a nylon membrane (Hybond N; Amersham Corp.) and hybridized to an estrogen receptor cDNA fragment (23). The size of the radiolabeled amplified DNA fragment was consistent with the distance between the primers.

Immunohistochemistry. Immunohistochemistry for the estrogen receptor was performed on formalin-fixed paraffin-embedded tissues by the method of O'Keane et al. (24). The primary antiserum was rabbit antiestradiol (Diagnostic Products Corp., Los Angeles, CA), or normal rabbit serum as a negative control, the bridging antibody was biotinylated swine antiserum to rabbit immunoglobulin (DAKOPATTS, Copenhagen, Denmark), followed by avidin-peroxidase complexes (DAKO Quik Staining Kit 40; DAKOPATTS). The staining was developed for $10 \mathrm{~min}$ in diaminobenzidine solution or for $25 \mathrm{~min}$ in a freshly prepared solution of 3-amino-9-ethyl-carbazol. Then the slides were rinsed in tap water, subsequently counterstained with Moyer hematoxylin, and mounted with Canada balsam or glycerol gelatine. The immunocytochemical assay of estrogen receptor with anti-17 $\beta$-estradiol antibody has been shown to be an accurate and specific method for the determination of estrogen receptors (24). Immunohistochemistry was performed for calcitonin with a polyclonal antibody (DAKOPATTS).

\section{Results}

Ovariectomy led to a small, nonsignificant decrease in PTH and calcitonin mRNA levels (Fig. 1). PTH mRNA and calcitonin mRNA levels were markedly increased by $17 \beta$-estradiol (Fig. 1). There was no difference for three control genes studied, namely, actin mRNA (Fig. $1 A$ ) which is derived from the total thyroparathyroid tissue, somatostatin mRNA, which is specific for the $C$ cells in the thyroparathyroid tissue (3), and the $1,25(\mathrm{OH})_{2} \mathrm{D}_{3}$ receptor mRNA levels, which is present in the parathyroid and $\mathrm{C}$ cells, but not in the thyroid follicle cells (20) (not shown). The effect of estrogen on PTH mRNA levels was present $6 \mathrm{~h}$ after a 73-nmol dose of $17 \beta$-estradiol, but less marked than at $24 \mathrm{~h}$ (not shown). At $24 \mathrm{~h}$ single doses of 73 $\mathrm{nmol}$ and $145 \mathrm{nmol} 17 \beta$-estradiol led to fourfold increases in mRNA levels for both PTH and calcitonin (Fig. 1). Similar increases in mRNA levels were present after $17 \beta$-estradiol was given by osmotic minipump at a dose of $12 \mathrm{pmol} / \mathrm{d}$ for 7 or 14 d (Fig. 1). There was no difference in serum calciums among the different groups of rats (results not shown). 17 $\beta$-Estradiol

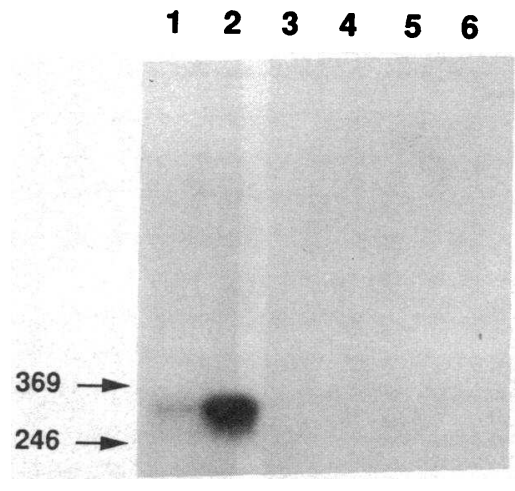

Figure 2. PCR products obtained by amplification of the rat estrogen receptor CDNA (ER cDNA) after reverse transcription of cellular RNA from female rat tissue were run on agarose gels and Southern blots hybridized with a ${ }^{32}$ P-labeled ER cDNA fragment. Lanes: 1 , thyroparathyroid tissue; 2, uterus; 3 , spleen; 4 , control without cDNA;

5, control without RNA; 6, control without reverse transcriptase. These controls demonstrate that there was no contamination with nonspecific DNA, RNA, or DNA in the RNA preparation. 
in these doses given to ovariectomized rats does not change serum 1,25-dihydroxyvitamin $D_{3}$ levels (25). These results demonstrate that estrogens regulate PTH and calcitonin gene expression in vivo. However, they do not demonstrate whether the estrogen effect was direct on the parathyroid and $C$ cells, or indirect, although one parameter of an indirect effect, serum calcium, did not change with ovariectomy or estrogen treatment.

Estrogen acts on its target organs by binding to a specific estrogen receptor; therefore, to investigate whether rat thyroparathyroid tissue was a candidate target organ for estrogens, we determined whether the estrogen receptor mRNA was present (23). PCR with estrogen receptor oligonucleotide primers using rat thyroparathyroid tissue RNA extracts showed a 311bp band specific for the estrogen receptor gene indicating that it is expressed in this tissue (Fig. 2). It was also expressed in the rat liver (not shown), and rat uterus but not in rat spleen (Fig. 2 ). Negative controls showed that there was no contamination in the PCR (Fig. 2). When PCR was performed on EcoRI restricted rat DNA with the same oligonucleotide primers a band of $\sim 850 \mathrm{bp}$ was demonstrated (not shown), which was larger than the $311-\mathrm{bp}$ band that was predicted from the distance between the primers in the estrogen receptor CDNA sequence. This larger PCR product presumably represents an intron, and confirms that there was no DNA contamination of the PCR reaction.
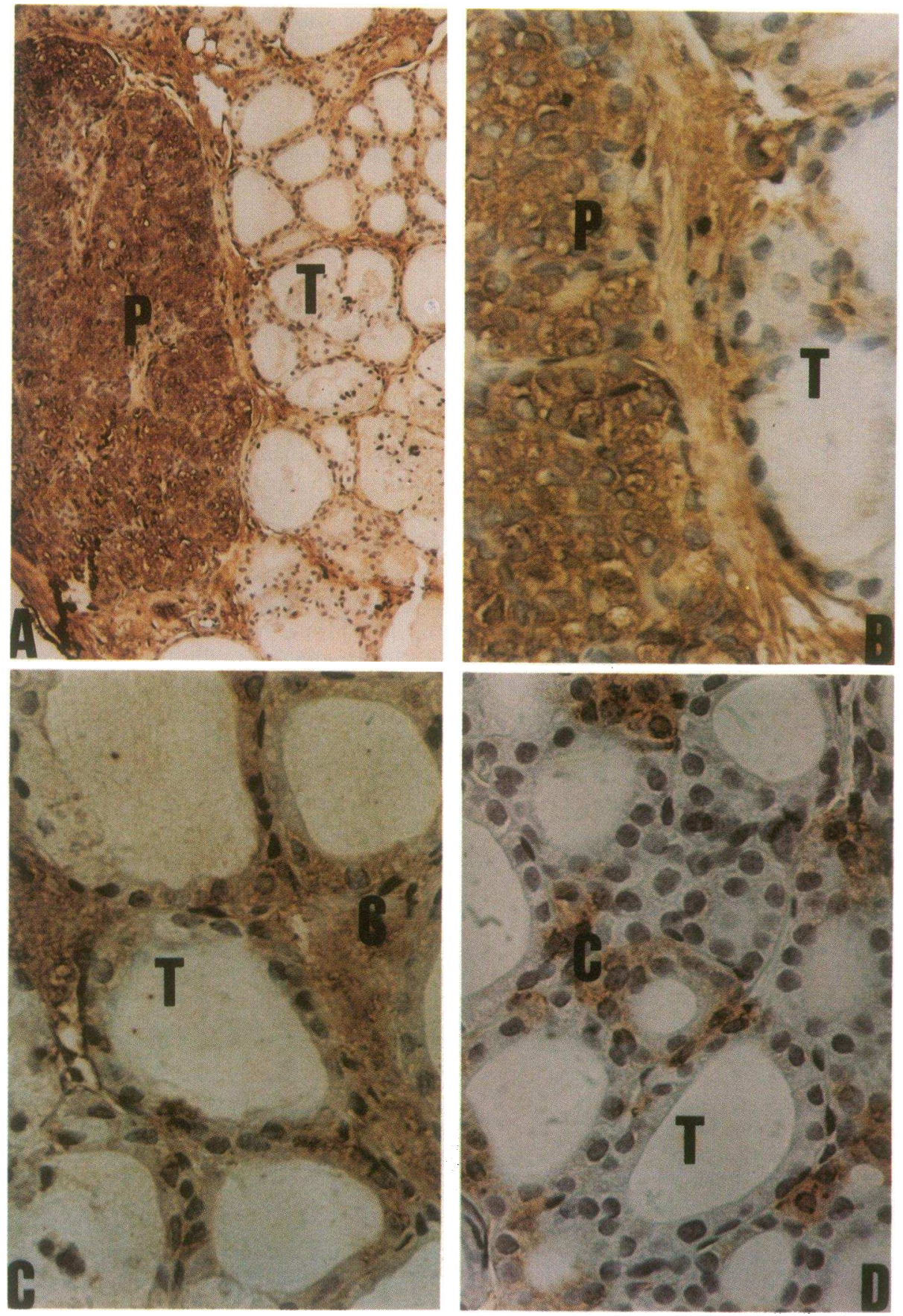

Figure 3. Immunohistochemistry for the estrogen receptor in female rat thyroparathyroid tissue $(A-C)$, and for calcitonin $(D)$, at magnifications of $100(A)$, and $400(B-D)$. P, parathyroid; $\mathrm{C}, \mathrm{C}$ cells; $\mathrm{T}$, thyroid follicles. There was nuclear and cytoplasmic staining in the parathyroid and $C$ cells, but not in the thyroid follicle cells. 
The PCR product in the rat thyroparathyroid tissue might have been a product of the thyroid follicles, $C$ cells, and parathyroid cells, and it was therefore necessary to demonstrate that the estrogen receptor was specific to the parathyroid and $\mathrm{C}$ cells, particularly because binding studies had not demonstrated an estrogen receptor in parathyroid tissue (26). We did this by immunohistochemistry using a polyclonal antibody to $17 \beta$-estradiol, whose staining specifically labels the estrogen receptor (24). In the rat thyroparathyroid tissue the estrogen receptor was found in the rat parathyroid and C cells, but not in the thyroid follicles (Fig. 3), or in spleen (not shown). Estrogen receptor was also present in bovine parathyroid tissue (not shown). As a negative control, normal rabbit serum was used instead of the primary antibody. As a positive control, rat uterus and the human ovary were used, where there was positive nuclear staining for the nuclear receptor. In the case of the human ovary, as expected, there was specific staining only of the granulosa cells (not shown). We also repeated these studies on both bovine parathyroid and rat thyroparathyroid tissue using 3-amino-9-ethyl-carbazol as the final stain instead of diaminobenzidine with identical results (not shown). Testosterone antibody did not stain the parathyroid or $\mathrm{C}$ cells. Together with the PCR, these results show that estrogen receptor gene and its protein are expressed in the parathyroid and $C$ cells.

Another parameter of estrogen activity was measured in these rats, namely, uterus weight. The uterotrophic effect of estrogens is a well-characterized biological response to administered estrogens. As expected, ovariectomy lead to a large decrease in uterus weight from a mean of $0.7 \mathrm{~g}$ to $0.15 \mathrm{~g}$ (Fig. 4). A pharmocological dose of $17 \beta$-estradiol $(73 \mathrm{nmol})$ given daily for $7 \mathrm{~d}$ increased uterus weight twofold. A much smaller dose ( $12 \mathrm{pmol} / \mathrm{d}$ ) given by a constant infusion pump for $2 \mathrm{wk}$ did not affect uterus weight (Fig. 4) despite its potent effect on PTH and calcitonin mRNA levels (Fig. 1). This small physiologically relevant dose successfully separated an estrogen effect on the calcium regulating hormones from that on the uterus.

\section{Discussion}

The action of estradiol to increase the expression of the PTH and calcitonin genes, and the presence of the estrogen receptor mRNA and protein in the parathyroid and C cells, as shown in

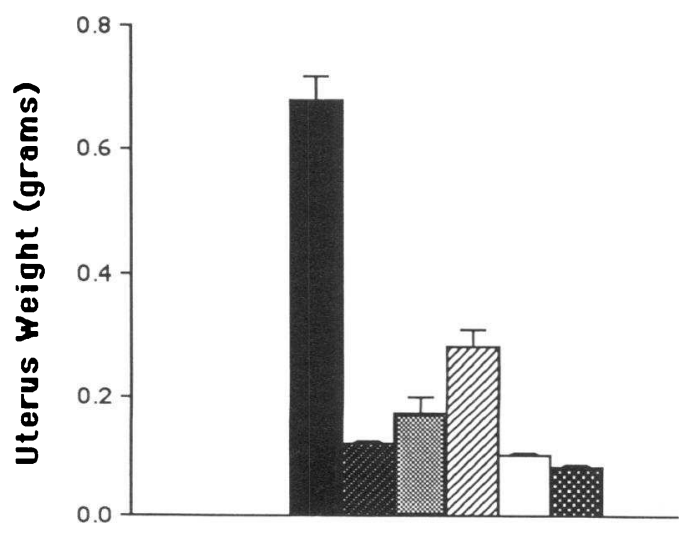

Figure 4. Uterus weight in sham, ovariectomized, and $17 \beta$-estradioltreated rats; estradiol was given in a single dose $(\times 1)$, or daily for 7 $\mathrm{d}(\times 7)$, or by minipump for 7 or $14 \mathrm{~d}(12 \mathrm{pmol} / \mathrm{d})$. Results are shown as the mean \pm SE for four rats. $₫$, Sham; $\square$, OVX; , E, $73 \mathrm{nmol}$ $\times 1$; $, \mathrm{E}, 73 \mathrm{nmol} \times 7$;, E minipump, $12 \mathrm{pmol} / \mathrm{d} \times 7$; $\mathrm{n}$, E minipump, $12 \mathrm{pmol} / \mathrm{d} \times 14$. this study, together with the earlier reports of a direct effect of estrogens to increase PTH and calcitonin secretion (16-19) establish that these two organs are target organs for estrogens. This effect of estrogens might be important to the normal physiology of calcium homeostasis, by the action of PTH and calcitonin on their target organs, especially bone. In physiologic concentrations, PTH is anabolic to bone by its effect on osteoblasts, which combined with the effect of calcitonin to decrease osteoclastic bone resorption, would result in stronger bones.

The effect of estrogens in patients with osteoporosis was to increase serum PTH levels (27-29) which was postulated to be secondary to an estrogen induced hypocalcemia $(27,29)$, whilst the effect on calcitonin levels was variable $(30,31)$ possibly due to the insensitivity of calcitonin immunoassays (32). Our results, together with the earlier in vitro reports of a direct effect of estrogens on PTH and calcitonin secretion (16-19), indicate that the effect of estrogens to increase PTH and calcitonin levels is a direct effect of estrogens on the parathyroid and $\mathrm{C}$ cells, respectively. In addition we have preliminary data with bovine parathyroid cells in primary culture, and a calcitonin producing cell line, that estrogens in vitro increase PTH and calcitonin mRNA levels, respectively (Naveh-Many, T., and J. Silver, unpublished results). In the present study serum PTH and calcitonin levels were not measured. However, to determine the importance of estrogens to their physiology it will be necessary to compare PTH and calcitonin mRNA levels, to their serum concentrations, both after the stress of ovariectomy and estrogen replacement, as well as during the normal estrous cycle.

Ovariectomy produces osteopenia in female rats which can be prevented by estrogen therapy $(33,34)$, or by the administration of parathyroid hormone (35) or diphosphonates (36), which, like calcitonin, inhibit bone resorption. In studies in osteoporotic patients PTH and calcitonin have been shown to have an anabolic effect on trabecular bone with an increase in vertebral bone density. These studies used PTH alone (37) or PTH with 1,25-dihydroxyvitamin $\mathrm{D}_{3}(38)$, or pulsatile PTH and sequential calcitonin (39). The present study suggests that estrogens act on bone to prevent osteoporosis not only by a direct action on osteoblasts but also indirectly by its action on the parathyroid gland and the $\mathrm{C}$ cells. Osteoblasts have estrogen receptors $(8,9)$, which are probably central to the effects of estrogen on bone, but it is intriguing that the body might use other mechanisms, such as an effect on PTH and calcitonin, to ensure normal bone strength.

$17 \beta$-Estradiol given at low doses by minipump for $2 \mathrm{wk}$ increased PTH and calcitonin mRNA levels with no uterotrophic effect as measured by uterus weight, which suggests that it might be possible to develop dose regimes for estrogens or estrogen analogues with an effect on the calcium regulating hormones but not on the female phenotypic organs. However, in the present study uterus weight was measured, and not the expression of uterus specific genes, which might be a more relevant parameter. The clearer understanding of estrogen action will allow the development of treatment strategies of relevance to every postmenopausal woman. This is particularly important, because although postmenopausal estrogen replacement leads to a reduction of $\sim 60 \%$ in hip fractures $(40)$, it may lead to a 1.3-fold increase in breast cancer (41) and a sixfold increase in uterine cancer (42). There is, therefore, an urgent need for new organ-specific estrogen compounds or dose regimes. The biological model, reported here, might allow the successful separation of estrogen's calciotrophic effect from 
its uterotrophic effect, which would be useful for the testing of such estrogen analogues.

\section{Acknowledgments}

We thank Miriam Offner for expert technical assistance, S. Green, M. G. Rosenfeld, H. Mayer, and J. W. Pike for clones, and H. Cedar for helpful advice.

This work was supported by grants from the National Institutes of Health (grant DK-38696), and the United States-Israel Binational Science Foundation.

\section{References}

1. Silver, J., T. Naveh-Many, H. Mayer, H. J. Schmelzer, and M. M. Popovtzer. 1986. Regulation by vitamin D metabolites of parathyroid hormone gene transcription in vivo in the rat. J. Clin. Invest. 78:1296-1301.

2. Naveh-Many, T., and J. Silver. 1990. Regulation of parathyroid hormone gene expression by hypocalcemia, hypercalcemia, and vitamin $\mathrm{D}$ in the rat. $J$. Clin. Invest. 86:1313-1319.

3. Naveh-Many, T., and J. Silver. 1988. Regulation of calcitonin gene transcription by vitamin D metabolites in vivo in the rat. J. Clin. Invest. 81:270-273.

4. Silver, J., J. Russell, and L. M. Sherwood. 1985. Regulation by vitamin D metabolites of messenger ribonucleic acid for preproparathyroid hormone in isolated bovine parathyroid cells. Proc. Natl. Acad. Sci. USA. 82:4270-4273.

5. Okazaki, T., T. Igarashi, and H. M. Kronenberg. 1988. 5'-flanking region of the parathyroid hormone gene mediates negative regulation by $1,25-(\mathrm{OH}) 2$ vitamin D3. J. Biol. Chem. 263:2203-2208.

6. Cote, G. J., D. G. Rogers, E. S. Huang, and R. F. Gagel. 1987. The effect of 1,25-dihydroxyvitamin D3 treatment on calcitonin and calcitonin gene-related peptide mRNA levels in cultured human thyroid C-cells. Biochem. Biophys. Res. Commun. 149:239-243.

7. Naveh-Many, T., M. M. Friedlaender, H. Mayer, and J. Silver. 1989. Calcium regulates parathyroid hormone messenger ribonucleic acid (mRNA), but not calcitonin mRNA in vivo in the rat. Dominant role of 1,25-dihydroxyvitamin D. Endocrinology. 125:275-280.

8. Eriksen, E. F., D. S. Clovard, N. J. Berg, M. L. Graham, K. G. Mann, T. C. Spelsberg, and B. L. Riggs. 1988. Evidence of estrogen receptors in normal human osteoblast-like cells. Science (Wash. DC). 241:84-86.

9. Komm, B. S., C. M. Terpening, D. J. Benz, K. A. Graeme, A. Gallegos, M. Korc, G. L. Greene, B. W. O'Malley, and M. R. Haussler. 1988. Estrogen binding, receptor mRNA, and biological response in osteoblast-like osteosarcoma cells. Science (Wash. DC). 241:81-84.

10. Fukayama, S., and A. H. J. Tashiian. 1989. Direct modulation by estradiol of the response of human bone cells ( $\mathrm{SaOS}-2)$ to human parathyroid hormone (PTH) and PTH-related protein. Endocrinology. 124:397-401.

11. Gray, T. K., T. C. Flynn, M. Gray, and L. M. Nabell. 1987. 17 $\beta$-Estradiol acts directly on the clonal osteoblastic cell line UMR 106. Proc. Natl. Acad. Sci. USA. 84:6267-6271.

12. Ernst, M., C. H. Schmid, and E. R. Froesch. 1988. Enhanced osteoblast proliferation and collagen gene expression by estradiol. Proc. Natl. Acad. Sci. USA. 85:2307-2310.

13. Ernst, M., J. K. Heath, and G. A. Rodan. 1989. Estradiol effects on proliferation, messenger ribonucleic acid for collagen and insulin-like growth factor-I, and parathyroid hormone-stimulated adenylate cyclase activity in osteoblastic cells from calvariae and long bones. Endocrinology. 125:825-833.

14. Mohan, S., J. C. Jennings, T. A. Linhhart, and D. Baylink. 1988. Primary structure of human skeletal growth factor: sequence homology with insulin-like growth factor-II. Biochim. Biophys. Acta. 996:44-55.

15. Rodan, G. A. 1991. Mechanical loading, estrogen deficiency, and the coupling of bone formation to bone resorption. J. Bone Miner. Res. 6:527-530.

16. Greenberg, C., S. C. Kukreja, E. N. Bowser, G. K. Hargis, W. J. Henderson, and G. A. Williams. 1987. Parathyroid hormone secretion: effect of estradiol and progesterone. Metab. Clin. Exp. 36:151-154.

17. Duarte, B. G. K. Hargis, and S. C. Kukreja. 1988. Effects of estradiol and progesterone on parathyroid hormone secretion from human parathyroid tissue. J. Clin. Endocrinol. \& Metab. 66:584-587.

18. Greenberg, C., S. C. Kukreja, E. N. Bowser, G. K. Hargis, W. J. Henderson, and G. A. Williams. 1986. Effects of estradiol and progesterone on calcitonin secretion. Endocrinology. 118:2594-2598.

19. Lazaretti-Castro, M., A. Grauer, Y. Mekonnen, F. Raue, and R. Ziegler 1991. Effects of $17 \beta$-estradiol on calcitonin secretion and content in a human medullary thyroid carcinoma cell line. J. Bone Miner. Res. 6:1191-1195.
20. Naveh-Many, T., R. Marx, E. Keshet, J. W. Pike, and J. Silver. 1990. Regulation of 1,25-dihydroxyvitamin $D_{3}$ receptor gene expression by 1,25-dihydroxyvitamin $\mathrm{D}_{3}$ in the parathyroid in vivo. J. Clin. Invest. 86:1968-1975.

21. Saiki, R. K., D. H. Gelfand, S. Stoffel, S. J. Scharf, R. Iguchi, G. T. Horn, B. Mullis, and H. A. Erlich. 1988. Primer-directed enzymatic amplification of DNA with a thermostable DNA polymerase. Science (Wash. DC). 239:487-491.

22. Kawasaki, E. S. 1990. Amplification of RNA. In PCR Protocols. A Guide to Methods and Applications. M. A. Innis, D. H. Gelfand, J. J. Sninsky, and T. J. White, editors. Academic Press, New York. 21-27.

23. Koike, S., M. Sakai, and M. Muramatsu. 1987. Molecular cloning and characterization of rat estrogen receptor cDNA. Nucleic Acids Res. 15:24992513

24. O'Keane, J. C., E. Okon, K. Moroz, B. Burke, K. Sheahan, and M. J. O'Brien. 1990. Anti-estradiol immunoperoxidase labeling of nuclei, not cytoplasm, in paraffin sections, determines estrogen receptor status of breast cancer. Am. J. Surg. Pathol. 14:121-127.

25. Turner, R. T., J. J. Vandersteenhoven, and N. H. Bell. 1987. The effects of ovariectomy and $17 \beta$-estradiol on cortical bone histomorphometry in growing rats. J. Bone Miner. Metab. 2:115-122.

26. Prince, R. L., D. T. MacLaughlin, R. D. Gaz, and R. M. Neer. 1991. Lack of evidence for estrogen receptors in human and bovine parathyroid tissue. $J$. Clin. Endocrinol. \& Metab. 72:1226-1228.

27. Gallagher, J. C., B. L. Riggs, and H. F. DeLuca. 1980. Effect of estrogen on calcium absorption and serum vitamin D metabolites in postmenopausal osteoporosis. J. Clin. Endocrinol. \& Metab. 51:1359-1364.

28. Silverberg, S. J., E. Shane, L. De La Cruz, G. V. Segre, T. L. Clemens, and J. P. Bilezikian. 1989. Abnormalities in parathyroid hormone secretion and 1,25dihydroxyvitamin $\mathrm{D}_{3}$ formation in women with osteoporosis. $N$. Engl. J. Med. 320:277-281

29. Prince, R. L., I. Schiff, and R. M. Neer. 1990. Effects of transdermal estrogen replacement on parathyroid hormone secretion. J. Clin. Endocrinol. \& Metab. 71:1284-1287.

30. Reginster, J. Y., R. Deroisy, A. Albert, D. Denis, M. P. Lecart, J. Collette, and P. Franchimont. 1989. Relationship between whole plasma calcitonin levels, calcitonin secretory capacity, and plasma levels of estrone in healthy women and postmenopausal osteoporotics. J. Clin. Invest. 83:1073-1077.

31. Hurley, D. L., R. D. Tiegs, J. Barta, K. Laakso, and H. Heath. 1989. Effects of oral contraceptive and estrogen administration on plasma calcitonin in pre- and postmenopausal women. J. Bone Miner. Res. 4:89-95.

32. Dick, I. M., and R. L. Prince. 1991. Transdermal estrogen replacement does not increase calcitonin secretory reserve in postmenopausal women. Acto Endocrinol. 125:241-245.

33. Takano-Yamamoto, T., and G. A. Rodan. 1990. Direct effects of $17 \beta-$ estradiol on trabecular bone in ovariectomized rats. Proc. Natl. Acad. Sci. USA. 87:2172-2176.

34. Kalu, D. N., C. C. Liu, E. Salemo, B. Hollis, R. Echon, and M. Ray. 1991. Skeletal responses of ovariectomized rats to low and high doses of $17 \beta$-estradiol. Bone Miner. 14:175-187.

35. Liu, C.-C., and D. N. Kalu. 1990. Human parathyroid hormone (1-34) prevents bone loss and augments bone formation in sexually mature ovariectomized rats. J. Bone Miner. Res. 5:973-982.

36. Wronski, T. J., C. F. Yen, and K. S. Scott. 1991. Estrogen and diphosphonate treatment provide long-term protection against osteopenia in ovariectomized rats. J Bone Miner. Metab. 6:387-394.

37. Reeve, J., P. J. Meunier, J. A. Parsons, M. Bernat, O. L. M. Bilvoet, P. Courpron, C. Edouard, L., Kleneman, R. M. Neer, J. C. Renier, et al. 1980. Anabolic effects of human parathyroid hormone fragment on trabecular bone in involutional osteoporosis: a multicentre trial. Br. Med. J. 280:1340-1344.

38. Slovik, D. M., D. I. Rosenthal, S. H. Doppelt, J. T. Potts, M. A. Daly, J. A. Campbell, and R. M. Neer. 1986. Restoration of spinal bone in osteoporotic men by treatment with human parathyroid hormone (1-34) and 1,25-dihydroxyvitamin D. J. Bone Miner. Res. 1:377-381.

39. Hesch, R.-D., U. Busch, M. Prokop, G. Delling, and E.-F. Rittinghaus. 1989. Increase of vertebral bone density by combination therapy with pulsatile $1-38 \mathrm{hPTH}$ and sequential addition of calcitonin nasal spray in osteoporotic patients. Calcif. Tissue Int. 44:176-180.

40. Kiel, D. P., D. T. Felson, J. J. Anderson, P. W. F. Wilson, and M. A Moskowitz. 1987. Hip fractures and the use of estrogens in postmenopausal women. N. Engl. J. Med. 817:1169-1174.

41. Colditz, G. A., M. J. Stampfer, W. C. Willett, C. H. Hennekens, B. Rosner and F. E. Speizer. 1990. Prospective study of estrogen replacement therapy and risk of breast cancer in postmenopausal women. JAMA (J. Am. Med. Assoc.). 264:2648-2653.

42. Goldman, L., and A. N. A. Tosteson. 1991. Uncertainty about postmenopausal estrogen. Time for action not debate. N. Engl. J. Med. 325:800-802. 